\title{
Basic characteristics of active tectonics in China
}

\begin{abstract}
The territory of China can be divided into seven active tectonic regions which show different basic features. Cenozoic tectonics belong to the Tethyan-Himalayan, and the Peri-Pacific tectonic domains. Active tectonics denotes Quaternary-present structures including active faults, folds, basins, blocks, and the Quaternary volcanoes and their assemblages. China lies on the southeastern part of the Eurasian plate, bordering the collision zone between the Indian and Eurasian plates on the south-west and the subduction zone between the Pacific and Eurasian plates to the east. The territory is made up of juxtaposed strongly deformed parts and relatively stable regions, and hence is characterized by complexity and diversity of active structures.
\end{abstract}

\section{Active tectonic regions}

The territory can be divided into seven active tectonic regions (Ma Xingyuan, 1987: Ma Xingyuan, 1988) as shown in Figure 1. These are described in turn:

1 The Qinghai-Xizang (Tibet) Plateau Region. By the direct effect of indentation of the Indian plate into the Eurasian continent, the whole region has been strongly uplifted since the late Tertiary A series of north-south-trending graben systems has developed in the south-central part of the plateau, while com pressional nappe structures or great strike-slip faults developed in the marginal parts of the plateau.

2 The North-west China Region. In this region, compressional structures predominate, including large-scale compression-depressional basins, compressional uplift blocks, active folds and active fault assemblages between them. The effect of collision between the Indian plate and the Asian continent weakened from the south to the north.

3 Taiwan Island Region. The Longitudinal Valley fault on the eastern coast of Taiwan Island is a convergence-collision boundary between the Philippine Sea and the Eurasian plate. It was an overthrust, with sinistral strike-slip components, from the Pliocene to the Pleistocene. Taiwan Island was an island arc under strong compression and its Central Mountain Range was the most strongly uplifted within the West Pacific Island-arc system. A subduction zone, where the Philippine Sea plate underthrusts northward, lies in the sea area north-east of the island and a series of arcuate overthrust structures protruded to the west. These were accompanied by compressional depressions in the western part of the island.

4 The South China Sea Region. Its central part was a small oceanic pull-apart basin during the Tertiary; local taphrogenesis is still taking place. Some major active faults at the boundaries occur in the periphery of the region. The South China Sea Region as a whole has undergone subsidence.

5 The South China Region. Tectonically, this region is the weakest part of China. It is generally in a slightly uplifted state and is being pushed eastwards by the Qinghai-Xizang plateau. Its south-eastern margin is undergoing strong faulting and volcanic aclivity by the tectonic effect from Taiwan Island and the South China Sea Regions.

6 The North China Region. This most active region in eastem China is characterized by a good development of mainly extensional shear normal faults and extensional basins, which are distributed in the periphery of the Ordos block, the North China plain and the North Jiangsu-South Huanghai Sea basin. The NNE-trending Tancheng-Lujiang fault zone passing through the North China Region is an active fault of dextral strike-slip and thrust nature.

7 The North-east China Region. In this region only slight faulting and differential movement, uplifting and depression have occurred. Quaternary volcanism however, is widely distributed and continued to be active in historic time in the Changbai Mountains and Wudalianchi zone. A deep-locus seismic zone is located in the Hunchun area along the national border.

\section{The nature of the boundaries between active tectonic regions and their kinematic characteristics}

The northern boundary of the Qinghai-Xizang Plateau region is clearly a sinistral shear lault zone consisting, from west to east, of the Altun, the northern Qilianshan piedmont, and the Haiyuan faults. Among these the Qilianshan fault segment shows a stronger thrust or overthrust movement component

The eastern boundary of the Qinghai-Xizang Plateau region can be divided into northern and southern segments. The northern segment extends from the liupang Mountains through a zone between the eastern and western Qinling ranges to Mingshan Mountain and is connected with the south-western Longmen Mountains segment. It is a newly formed hidden dispersed boundary, locally showing compressional folds, uplifts and nappe structures. A dense earthquake zone from Tianshui, Wudu through Songpan to Baoxing, is a clear indicator of the boundary. The southern segment represents a wide deformation zone, which can be traced into the eastern and western branches of the active fault zone. The eastern branch is the Xianshuihe-Anninghe-Xiaojiang sinistral strike-slip fault zone, while the western branch is the Nujiang-Honghe dextral strike-slip fault zone. The rhombic Sichuan-Yunnan block between them moves in a SSE direction.

The northern boundary of the North China region represents a dispersed boundary extending from the Hetao basin, Nei Mongol, on the west, through the Zhangjiakou and Yanqing-Huailai basins, along the southern Yanshan piedmont south-eastward to the Bohai Sea. It is a complex tectonic zone consisting of a series of Cenozoic to Quaternary extensional basins and active faults. The level of seismicity in the zone is comparatively high. Analysis of structural combinations and focal mechanism solutions indicates a sinistral movement of blocks on both sides of the fault zone. Seismic reflection profiling in the central part of Bohai Sea shows a sinistral offset of the Tancheng-Lujiang fault by WNW-trending faults.

The southern boundary of the North China region extends from the northern Qinling piedmont fault on the west, spreads out eastward into several WNW-trending en-echelon faults on the Qinling Mountains, and continues south-eastward to the Tongbai Mountains and the northern Dabie Mountain piedmont. It then extends eastward in the form of dispersed faults through South Anhui, South 
Jiangsu, across the Changiiang Estuary to the southern Huanghai Sea. Its Qinling segment represents mainly a normal fault, but has locally undergone sinistral strike-slip movement. Its activity reduces eastward to the Dabie Mountain.

\section{Mode and amount of the relative movement of active blocks}

\section{The nature and mobility of the active faults}

During the last ten years large-scale geologic mapping and multidisciplinary research of the major active faults in China have enabled us to reach the following conclusions:
- The faults on the border of Qinghai-Xizang Plateau are mainly of compressional shear or shear characters, with their mean strike-slip rate about $5-15 \mathrm{~mm} / \mathrm{a}$ during the Holocene.

- The North-west China region is characterized by compressional thrust or overthrust faulting, accompanjed by Quaternary folding, with a mean thrust-normal slip rate of $0.5 \mathrm{~mm} / \mathrm{a}$ on thrust faults.

- The eastern China region is dominated by normal faulting or strike-slip normal faulting, with the normal slip rate mostly less than $3 \mathrm{~mm} / \mathrm{a}$ on dip-slip faults.

\section{Relative movement of the blocks within the Qinghai-Xizang Plateau}

Many sutures occurring within the Qinghai-Xizang Plateau have turned eastward to form arcuate fault zones cutting the eastern part

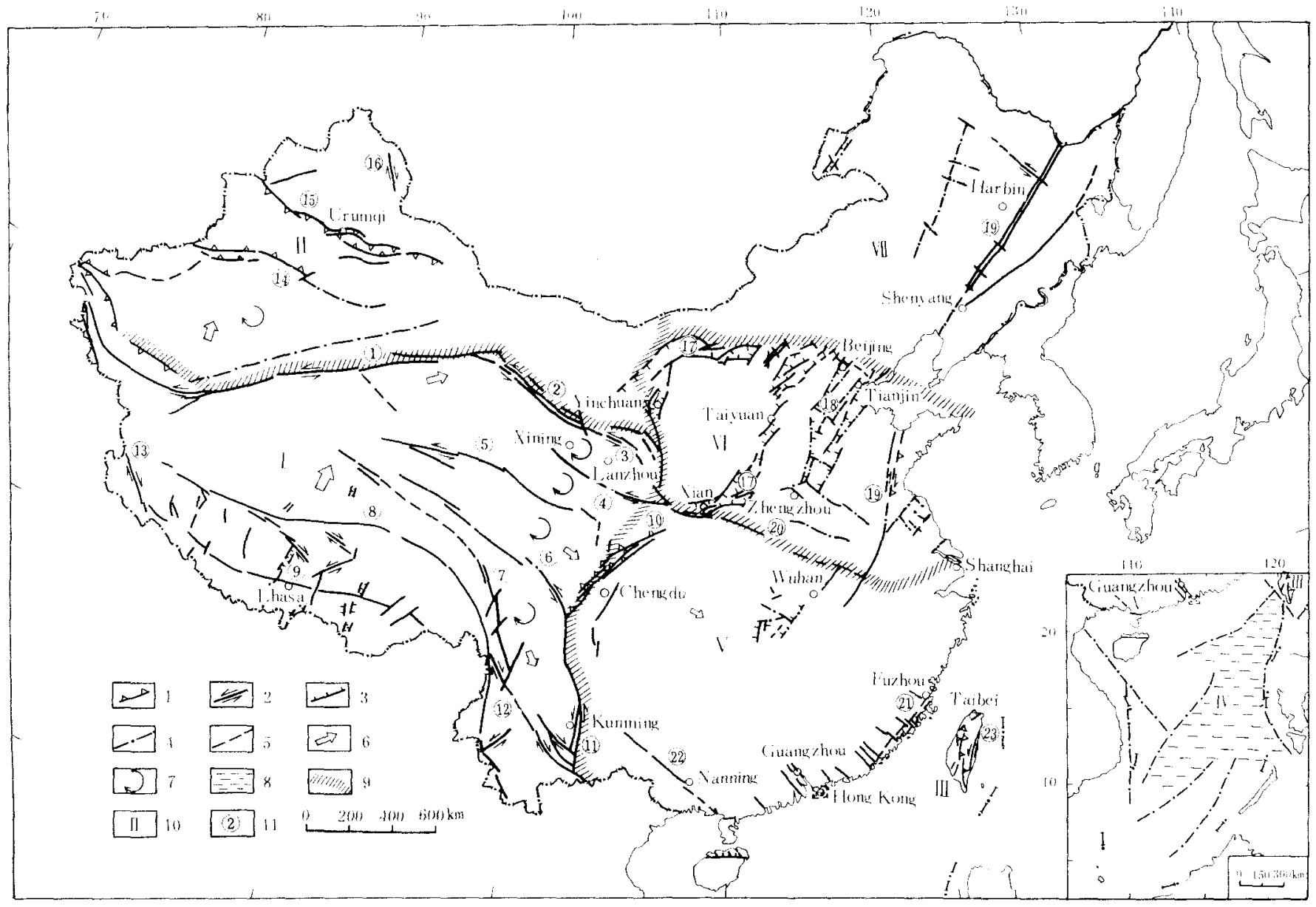

Figure I Active tectonic regions of China.

(National boundary from Geographical Map of China, 1:10000 000 scale, China Geographical Maps Publishing House, 1990)

1 Thrust or overthrust fault

2 Strike-slip fault

3 Normal fault

4 Buried active fault

5 Inferred active fault

6 Direction of block motion

7 Block rotation pattern

8 Basin with oceanic crust

9 Boundary between active tectonic regions

10 Active-tectonic region and its number

11 Active fault and its number.

Active-tectonic regions

I Qinghai-Xizang (Tibet) Plateau Region

II North-west China Region

III Taiwan Island Region

IV South China Sea Region

$V$ South China Region

VI North China Region

VII North-east China Region.
Active faults

1 Altun Fault

2 Qilianshan Fault

3 Haiyuan Fault

4 West Qinling Fault

5 East Kunlun Fault

6 Xianshuihe Fault

7 Jinshajiang Fault

8 Nujiang Fault

9 Varlun Zangbo Fault

10 Longmenshan Fault

12 Xiaojiang Fault
13 Karakorum Fault

14 Southern Tianshan Piedmont Fault

15 Northern Tianshan Fault

16 Koktokay-Ertai Fault

17 Fault System in the periphery of Ordos

18 Fault System in Hebei Plain

19 Tancheng-Lujiang Fault

20 Oinling Fault

21 Changle-Shao'an Fault

22 Youjiang Fault

2.3 Longitudinal Valley Fault 
of the plateau into several strip blocks. The movement of the plateau blocks exhibits the following features:

- A series of sub-meridional grabens in the southern part of the plateau have caused the southern Xizang block to shorten in a north-south direction and extend in an east-west direction.

- The northern part of the plateau has undergone northeastern motion controlled by sinistral strike-slip movement along the northern boundary of the northern part of the plateau.

- The eastern part of the plateau was cut by the northern West Qinling piedmont, the East Kunlun, and Xianshuihe sinistral strike-slip faults into several strip blocks, which successively move eastward and may be accompanied with clockwise rotation or torque deformation, i.e. the so-called step-over faulting or domino-type faulting.

\section{Block movement in the north-west China region}

The rigid Tarim and Junggar blocks alternate with the more ductile Tianshan and Altay blocks in a sub-meridional compressional environment. The main contractional deformation took place on the marginal parts of the mountainous blocks, expressed as active folds and active nappes. Pushed by the Qinghai-Xizang Plateau, the Tarim and Junggar blocks moved northward. However the pushing force decreased toward the north. Moreover, the Tarim block has rotated clock wise relatively to the Siberian block.

\section{Relative movement of the eastern China blocks}

The relative movement of the North China and South China blocks remains a problem to be solved. Some geoscientists believe that the lateral pushing of the Qinghai-Xizang Plateau has caused sinistral shear movement in the South China block relative to the North China block. However, considering the very limited distribution of sinistral strike-slip faults along the southern boundary of the North China region, so far no single continuous sinistral shear boundary tectonic zone, with certain movement intensity, has been confirmed and there is no evident sinistral dislocation of the NNE-trending. linear Tancheng-Lujiang fault zone at Dabie mountain. Therefore, the large relative movement of the North China and South China blocks is not yet proved. The NNE- and NW-trending active faults in the North China block have dextral and sinistral strike-slip components respectively. The blocks separated by the Shanxi graben system, the eastern Taihang piedmont fault and the Tancheng-Lujiang fault might have undergone counter-clockwise rotation or torque deformation by the effect of dextral shearing along the faults. However. the amount of the dextral movement is small and hence the deformation is limited in intensity.

\section{Discussion on the lithospheric dynamics of China}

\section{The Tethyan-Himalayan tectonic domain and the peri-Pacific tectonic domain}

Some Chinese geoscientists consider that China comprises two tectonic domains on the basis of Cenozoic structures: the TethyanHimalayan tectonic domain and Peri-Pacific tectonic domain. These are separated by the North-South tectonic zone (Ren Jishun et al., 1980). However, others emphasize the effect of indentation by the Indian subcontinent of the Eurasian continent and attribute the formation of the Baikalian rift, North China rift-graben system, and the opening of the South China Sea to the lateral movement of the Qing hai-Xizang block (Tapponnier et al., 1977; Briais et al., 1993).

As we discussed in detail in a previous paper (Ma Xingyuan et al., 1982), the taphrogenic process in North China, beginning in the Eocene, is related to increasing activity in the upper mantle beneath the West Pacific back-arc and the intensity increases from west to east. The taphrogenic process began carlier in the North-east China region, but the magmatism continued into the Quaternary, corresponding well with the reported tectonic-magmatic cycle in the Japanese Island-arc, its temporal-spatial evolution, and its petrochemical characteristics. The active structures and magmatic activity in the South China region were evidently related to the movement on the margin of the Philippine Sea plate and the taphrogenic process in the South China Sea.

Therefore, the division of China into two large tectonic domains is generally reasonable. However. mention should be made of some new Pliocene-to-Quaternary phenomena recently observed in the western Ordos area of North China. Firstly, the pulling apart of the Shanxi graben system reflects a dextral shear movement of blocks on both of its sides; secondly, the Quaternary deposits in the peripheral basins of the Ordos block markedly thickened westward. This may indicate that the gradual uplifting of the Qinghaj-Xizang Plateau has increasingly affected the surrounding blocks. In other words, during the Quaternary, the western part of the North China region was affected by the lateral movement of the Qinghai-Xizang Platcau and became an area of superposition and interaction between these two large tectonic domains (Wang Yipeng et al., 1986).

To the north of the plateiu, the Jurassic and Tertiary deposits on the north-eastern border of the Junggar block have not been deformed. The Quaternary deposits and geomorphic development are quite different from those on either side of the Tianshan Mountains, but are comparable with those in Mongol-Altay region. Their features are related to the tectonic stress field built up in the Siberian block and Baikalian rift which seems to have been produced by upper mantle mass upwelling and diapirism in the continental lithosphere. It seems that the northern limit of the influence of collision of Indian Plate might roughly coincide with the Junggar block.

\section{The amount of lateral squeeze by the Qinghai- Xizang Plateau and the occurrence of the North-South tectonic zone}

The estimation of the amount of eastward squeczing is a focus in the controversy over the kinematic model of Qinghai-Xizang Plateau. Some have suggested that the squeeze amount does not exceed $20 \%$ of the indentation of Indian Plate (Davy et al., 1988; England et al., 1986); others favour large-scale squeezing, constituting more than $50 \%$ of the indentation (Armijo et al., 1989; Avouac et al., 1993)

The northern and eastern boundaries of the Qinghai-Xizang Plateau are of two types: the frontal nappe type and the lateral strikeslip type. The former refers to the thrust or overthrust faults confining the plateat, which is undergoing an outward obduction, as in the West Kunlun, Qilianshan, Liupangshan, and Longmenshan segments. It acts as a convergence zone between the intracontinental blocks, through which the plateau transmits stress to its adjacent blocks which are displaced and deformed. The Ordos, South China and the Tarim blocks could be affected by this pushing. The socalled lateral strike-slip type refers to the strike-slip faults which have caused the blocks on the border of the plateau to move out of the plateau. Some of these faults obliquely cut the border of the plateau and others are distributed in an arcuate zone. The northern boundary of the plateau is a large-scale sinistral shear tectonic belt. along which the northern part of the plateau moves eastward. However, the mean Holocene slip-rate data obtained so far indicate that the movement gradually weakens from west to east, and only nappe shortening appears in the mountain zones of Liupang Longmen. It seems that the north-eastern part of the plateau has not moved eastward across the north-south tectonic zone on a large scale. As previously analysed, the eastward squeeze of the South China block together with the Qinling Range has nol reached a scale large enough to cause the shear slip tectonic zone to be penetrated. At the southeastern side of the plateau, the southward movement of the rhombic Sichuan-Yunnan block may be confirmed, but the detailed geologic 
mapping of the Honghe (Red River) fault zone suggests that the slip rate along the fault zone decreased from north-west to south-east and the movement terminated earlier. No late Quaternary surface displacement was found on the south-eastern segment of the Honghe fault. Therefore, there is a tendency for the south-eastward movement of the plateau blocks to gradually decrease in time and space. It follows that the amount of lateral squeeze of the Qinghai-Xizang Plateau during the Quaternary was not extremely significant.

A wide north-south tectonic belt separates eastern from western China at $102^{\circ}-105^{\circ} \mathrm{E}$. It is actually a great dextral shear belt formed by the northward wedging of the Qinghai-Xizang Plateau (England et al., 1990). The subordinate arcuate fault zones within the shear belt are predominated by sinistral strike-slip movement and the strip-like blocks separated by the faults must have undergone clockwise rotation or torque deformation. This deformation has partially absorbed the lateral slip of the eastern plateau.

\section{The development of the Cenozoic crustal movement pattern and the start of the present pattern}

There is much controversy over the amount of lateral squeezingof the plateau from the difference in observation data on the one hand, and from the age determination of the present crustal movement on the other. Some researchers believe that in Miocene time the plateau reached a considerable height and that during the middle and late Miocene, Himalayan movements gave rise to the pattern of crustal movement within and outside the plateau, as seen today. On this basis, they estimate a total displacement in the order of up to several hundred kilometres on some major strike-slip faults. But field investigations on the active faults within the Qinghai-Xizang Plateau and its surrounding areas during recent years suggest that the total displacement along the faults confirmed by the displacement of geological-geomorphlogical bodies is usually only a few kilometres, tens at most. The nature of the fault activity may not have been constant since the late Tertiary. On the contrary, many strike-slip faults have evolved from an early strong compressional thrust to a late typical strike-slip feature. The time of this change in movement pattern differs from area to area, but is mostly early Quaternary. Thus, we may assume that since the strong Himalayan orogeny in the Miocene, with the continuous compression, uplift and northward indentation of the plateau, the lithospheric structure; the properties of the component materials; the relative position of the plateau and its adjacent blocks, and the stress state over them have changed continuously. By some undefined mechanism (for instance, the mass flow in the lithosphere caused by high gravity potential), the crustal movement pattern evolved by a gradual increase in the lateral displacement of the plateau outwards. The sub-meridional graben system in the southcentral part of the Xizang Plateau was developed mostly in the early-middle Quaternary.

\section{Acknowledgement}

The authors are most grateful to Professor Liangmou Wang for his help in the compilation of Figure 1.

\section{References}

Armijo, R, Tapponnier, P, and Han, T, 1989, Late Cenozoic right lateral strike-slip faulting in southern Tibet: Journal of Geophysical Research, v. 94, pp. 2787-2838.

Avouac, J P, and Tapponnier, P, 1993, Kinematic model of active deformation in the Central Asia: Geophysical Research Letters, v. 20, no. 10, pp. 895-898.
Briais, A, Patriat, P, and Tapponnier, P, 1993, Updated interpretation of magnetic anomalies and seafloor spreading stages in the Tertiary tectonics of Southeast Asia: Journal of Geophysical Research, v. 98, no. B4, pp. $6299-6328$.

Davy, P, and Cobbold, P R, 1988, Indentation tectonics in nature and experiments 1. 2: Bulletin Geological Institute Upsala, 14, pp. 129-162.

England, P, and Houseman, G, 1986, Finite strain calculation of continental deformation, 2, Comparison with the India-Asia collision zone: Journal of Geophysical Research, v. 91, pp. 3664-3676.

England, P, and Molnar, P, 1990, Right-lateral shear and rotation as the explanation for strike-slip in eastern Tibet: Nature, v. 344, pp. 140-142.

Ma Xingyuan, Deng Q, Wang Y, and Liu H, 1982, Cenozoic graben system in North China: Zeitschrift fuer Geomorphologie Neue Folge, Supplement, band 42, pp. 99-106.

Ma Xingyuan, 1987, Explanation Notes for the Lithospheric Dynamics Map of China and Adjacent Seas, Scale 1:1,000,000: Geological Publishing House, Beijing.

Ma Xingyuan, 1988, Lithospheric dynamics of China. Episodes, v. 11, no. 2, pp. $84-90$.

Ren Jishun, Jiang Chunfa, Zhang Zhengkun, and Qin Deyu, 1980, Geotectonics of China and its Evolution: Science Press, Beijing, pp. 111-116.

Tapponnier, P, and Molnar, P, 1979, Active faulting and Cenozoic tectonics, of the Tien Shan, Mongolia and Baikal regions: Journal of Geophysical Research, v. 84, pp. 3425-3459.

Wang Yipeng, Song Fangming, Liao Yuhua, Zhang Weichi, Huai Fupeng and Liu Ping, 1986, Some characteristics of seismo-geology of northern Ningxia, with a discussion on the effect of Qinghai-Xizang Plateau on the crustal stress field in North China: Research on Recent Crustal Movement, no. 2, Seismological Press, Beijing, pp. 7-18 (in Chinese).

Yipeng Wang, is Professor of Geology, and Head of the Active Tectonics Division of the Institute of Geology, State Seismological Bureau of China. He started his career in geology in 1963 when he graduated from Peking University. At the Institute of Geology, Academia Sinica, he has conducted research on tectonics in areas of of East China, the Himalayas and the Qinghai-Xizang Plateau, Recently he has focused attention on active faults at engineering construction sites.

Xingyuan Ma graduated from the Earth Sciences Department of National Southwest Associated University, Kunming, in 1942. In 1946, he went to study in the UK and completed his PhD thesis under the late Professor Arthur Holmes in 1948. Afterwards he worked in the Geological Department of Peking University and Geoscience University. He moved to the State Seismological Bureau in 1978. He has carried out regional geological surveys in many areas of China. His work on basement and active tectonics has contributed both to the understanding of the early crustal evolution and also to the study of multi-layered seismicity
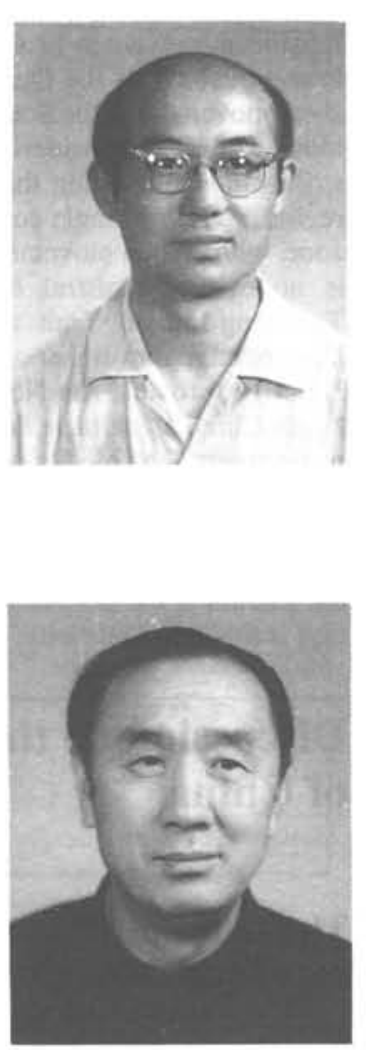